analiza pojęciowa. Pewne wątpliwości może również budzić zaproponowana definicja praw dziecka do edukacji. Autorka słusznie wskazuje na społeczno-kulturowy kontekst tego prawa, wydaje się, że nie dostrzega jednak jego normatywności; uwzględnienie tego faktu, pozwoliłoby dostrzec zmienność między innymi historyczną, religijną czy kulturową prawa dziecka do edukacji. Otwiera to również drogę do dalszych badań, na przykład nad możliwością sformułowania uniwersalnych standardów omawianych praw.

Podsumowując, Małgorzata Kozak w omawianej pracy zrealizowała postawione przed sobą zadanie; skonstruowała oryginalny zarys koncepcji prawa dziecka do edukacji i podjęła się z powodzeniem próby jej weryfikacji. Mimo pewnych niedociągnięć, książka ta stanowi wartościową i nowatorską propozycję, która powinna stać się obowiązkową lekturą dla badaczy pogranicza pedagogiki i prawa.

Tomasz Leś*

\title{
Simon Baron-Cohen, The Science of Evil. On Empathy and The Ori- gins of Cruelty, Basic Books, New York 2012, ss. 256**.
}

DOI: http://dx.doi.org/10.12775/PCh.2014.019

S. Baron-Cohen, światowej sławy naukowiec zajmujący się między innymi badaniami nad autyzmem i jego mózgowym podłożem, w publikacji zatytułowanej The Science of Evil. On Empathy and The Origins of Cruelty zadaje ważne i fundamentalne pytanie o podłoże i przyczyny zła, wyrządzanego przez jednego człowieka drugiemu. Jak sam podkreśla, chce wyprowadzić dyskusję dotyczącą zła z „królestwa religii” i wprowadzić ją w „królestwo nauki” (s. 151). Autor nie zadowala się odpowiedzią, że ludzie popełniają niewyobrażalne okrucieństwo, bo są źli - on stara się pójść dalej i dociec przyczyn tego zła. Wychodząc poza rozważania o moralności, próbuje znaleźć naukowe dowody na to, dlaczego ludzie dopuszczają się zbrodni, których ofiarami padają inni.

* Dr Tomasz Leś jest asystentem w Zakładzie Pedagogiki Ogólnej i Filozoficznej w Instytucie Pedagogiki Uniwersytetu Jagiellońskiego.

** Książka ta została wydana na rynku amerykańskim pod takim tytułem, a na rynku brytyjskim jako Zero Degrees of Empathy. Niedawno została przetłumaczona także na język 
Baron-Cohen zauważa, że niektórzy ludzie zadają cierpienie drugiemu, bo bardzo często nie traktują tej osoby jako człowieka - ale jako bezduszną, niezdolną do odczuwania cierpienia istotę - wręcz jako obiekt. Zło związane jest więc ze zjawiskiem, które Autor nazywa „erozją empatii” i które rozpoczyna się wraz z uprzedmiotowieniem drugiej osoby. Erozja empatii nie jest tak naprawdę czymś niezwykłym i może wystąpić w wielu sytuacjach życia codziennego, między innymi pojawia się jako efekt odczuwanego strachu, żądzy zemsty, nienawiści, ale także potrzeby ochrony i opieki innych. Na szczęście $\mathrm{w}$ wielu przypadkach jest zjawiskiem odwracalnym i przejściowym, wynikającym z zaistniałej sytuacji. W innych - jest trwała i związana $\mathrm{z}$ bardziej stałymi cechami psychologicznymi. I to ten typ erozji może nieść za sobą poważne konsekwencje.

Erozja empatii - jak zauważono wcześniej - jest związana właśnie $\mathrm{z}$ uprzedmiotowieniem drugiej osoby, $\mathrm{z}$ traktowaniem jej jako narzędzia używanego do osiągnięcia określonych celów, z pozbawieniem jej prawa do przeżywania uczuć czy indywidualnego myślenia. Baron-Cohen uważa, że takie podejście do drugiej osoby, odebranie jej człowieczeństwa, jest „najgorszą rzeczą, jaką można zrobić drugiej istocie ludzkiej” (s. 8).

Baron-Cohen, szukając przyczyn erozji empatii, analizuje także badania dotyczące neuroobrazowania związane z odkrywaniem obszarów mózgu odpowiedzialnych za odczuwanie empatii. Nazywa je „obwodem empatii” (empathy circuit) i prezentuje wyniki badań pokazujące różnice w funkcjonowaniu określonych części mózgu wśród osób o różnym poziomie empatii czy z zaburzeniami z tego zakresu.

Autor zakłada ponadto, że każdy człowiek mieści się na kontinuum empatii - zdobywając od zera do sześciu punktów. Osoby, które osiągają zerowe rezultaty, tzn. nie odczuwają empatii, mają trudności w rozumieniu uczuć i emocji, nie potrafią dostrzegać krzywd wyrządzanych innym, bo nie potrafią przyjąć perspektywy drugiej osoby. Nie zawsze jednak zerowy stopień empatii wiąże się z równie negatywnymi konsekwencjami - osoby bez empatii można bowiem pogrupować w dwie odrębne kategorie: takie, które są „,zero-negatywne” i takie, które są „zero-pozytywne”. W pierwszej z nich Autor wyodrębnia trzy podgrupy: osoby z zaburzeniami osobowości z pogranicza (borderline), osoby psychopatyczne i narcystyczne. Osoby, reprezentujące każdą z tych trzech kategorii, różnią się sposobem funkcjonowania, ale wszystkie one mają trudności z okazywaniem i odczuwaniem

polski i wydana pod tytułem Teoria Zła: O Empatii i Genezie Okrucieństwa, Sopot: Wydawnictwo Smak Słowa 2014, s. 212. 
empatii - i tak na przykład psychopaci ${ }^{1}$ nie mają trudności z odczytywaniem emocji (zachowany jest komponent afektywny), ale nie przejmują się tymi emocjami - cierpienie drugiej osoby nie powstrzymuje ich działania (zaburzenia w zakresie komponentu poznawczego). Autor zdaje sobie sprawę i wyraźnie podkreśla, że lista zaburzeń, których cechą wspólną jest brak empatii, nie jest kompletna - podejrzewa bowiem, że są inne zaburzenia, które - jeśli zająć się nimi właśnie z perspektywy empatii - wpisywałyby się w tę kategorię. Niektórzy badacze zastanawiają się, czy zaburzenia odżywiania - szczególnie anoreksja psychiczna - nie powinny należeć do tej grupy.

Z kolei osoby „zero-pozytywne” niekoniecznie są osobami, które będą zadawały świadome cierpienie - ich mózgi funkcjonują w podobny sposób, ale efekt jest inny - zaliczyć można tutaj między innymi osoby autystyczne czy z zespołem Aspergera. Są to osoby, które często nie potrafią odczytać emocji czy uczyć (a więc komponent poznawczy empatii jest zaburzony), ale jednocześnie troszczą się o innych (komponent afektywny pozostaje więc niezaburzony).

Autor zastanawia się również, jak rozwija się brak empatii. Obok czynników genetycznych podkreśla on znaczenie środowiska - a w szczególności rolę wczesnego etapu rozwoju. Baron-Cohen odnosi się do teorii przywiązania - zauważa on, że bezpieczne przywiązanie staje się dla dziecka „wewnętrznym dzbankiem złota” (internal pot of gold) - walutą na całe życie, której wartości w żaden sposób nie można przecenić. Zaniedbanie, przemoc i różne formy wykorzystywania mogą przyczynić się do trudności w rozwoju empatii.

Książka składa się z 6 rozdziałów, 2 aneksów, przypisów, indeksu i bibliografii oraz podziękowań. Mimo powoływania się na wiele źródeł, cytowania badań $\mathrm{z}$ różnych dziedzin, napisana jest językiem przystępnym. Zawiera wiele przykładów - zarówno opisów przypadków klinicznych, jak i doniesień medialnych - co zdecydowanie uatrakcyjnia lekturę. Dużą zaletą jest również układ książki i logiczne powiązanie ze sobą poszczególnych fragmentów. Na uwagę zasługują również ciekawie skomponowane aneksy.

Niewątpliwie Autor porusza ważne pytanie, na które badacze z różnych dyscyplin od wielu lat nie potrafią znaleźć odpowiedzi - dlaczego ludzie czynią zło i czy zło jest wynikiem ,zepsucia człowieka” - jego skaz charakterologicznych, genów czy środowiska, w którym przebywa. Wiele eksperymentów psychologicznych - czy to słynny Stanfordzki Eksperyment

1 Autor posługuje się tym pojęciem, choć zdaje sobie sprawę, że jest ono zastępowane innymi określeniami, na przykład „osobowość antyspołeczna”. 
Więzienny Zimbardo czy eksperyment Milgrama - próbowały wcześniej odpowiedzieć na pytanie o naturę zła. Jednak Baron-Cohen zauważa i podkreśla rolę empatii - mówiąc wprost, że jest ona najbardziej wartościowym zasobem na świecie. Zaburzenia, o których pisze, nie są czymś nowym - są opisywane między innymi w psychiatrii od wielu lat, ale perspektywa, którą prezentuje, jest nowatorska - bo każe w centrum uwagi i zainteresowań naukowców postawić właśnie empatię. Być może takie podejście wyznaczy nowy trend w badaniach nad zaburzeniami psychicznymi, motywacją do działań przestępczych czy motywacją do zadawania cierpienia drugiej osobie. Szczególnie że dzięki rozwojowi nowoczesnych technologii można nie tylko lepiej poznać to, jak pracuje mózg, ale i starać się konstruować leczenie i rehabilitację tak, aby poprawić funkcjonowanie tych obszarów, w których pojawiają się pewne deficyty. Ważne jest również to, że Autor choć opisuje zarówno geny, jak i obszary mózgu odpowiedzialne za empatię, nie twierdzi, że jest ona tylko i wyłącznie wynikiem działania mechanizmów dziedzicznych. Jasno podkreśla, że biologiczne podłoże zawsze współdziała ze środowiskiem, w którym dana osoba się wychowuje.

Reasumując, recenzowana pozycja jest ciekawą pracą, która w temacie, stanowiącym przedmiot dyskusji i badań wielu naukowców, reprezentujących różne dziedziny, rzuca nowe światło.

Lidia Anna Wiśniewska*

* Dr Lidia Anna Wiśniewska jest adiunktem w Katedrze Psychologii Wydziału Nauk Pedagogicznych Uniwersytetu Mikołaja Kopernika w Toruniu. 